Thabiea : Journal of Natural Science Teaching
Program Studi Tadris Ilmu Pengetahuan Alam
Institut Agama Islam Negeri Kudus
http://journal.stainkudus.ac.id/index.php/Thabiea
$p$-issn: 25808474

\title{
Deskripsi Kesulitan Belajar Materi Fisika pada Siswa Sekolah Menengah Pertama (SMP) Di Kota Semarang
}

Arghob Khofya Haqiqi ${ }^{1, a}$, Latifatus Sa'adah ${ }^{2}$

${ }^{1,2}$ Prodi Tadris IPA, Institut Agama Islam Negeri (IAIN) Kudus

aarghobhaqiqi@stainkudus.ac.id

\begin{tabular}{ll}
\hline Kata Kunci & ABSTRAK \\
\hline Deskripsi & Penelitian ini bertujuan untuk menemukan dan mendeskripsikan jenis jenis \\
Kesulitan Belajar & kesulitan belajar fisika pada siswa Sekolah Menengah Pertama (SMP) di \\
Fisika & Kota Semarang. Sampel penelitian dalam penelitian ini yaitu siswa SMP \\
& kelas VIII di Kota Semarang yang ditentukan secara cluster sampling \\
& menurut peringkat sekolah dilihat dari hasil nilai ujian nasional. Analisis \\
& data dilakukan secara deskriptif, data yang diperoleh dalam penelitian ini \\
& berupa data hasil belajar siswa pada materi cahaya kelas VIII. \\
& Hasil dari analisis hasil belajar siswa tersebut didapatkan kesulitan belajar \\
& fisika siswa SMP di Kota Semarang secara umum meliputi indikator \\
& kesulitan belajar berhitung 41,48 \%, kesulitan pemahaman konsep 42,3\% \\
& serta kesulitan mengartikan lambang dan mengkoversi satuan 37,89\%.
\end{tabular}

Adanya deskripsi kesulitan belajar ini dapat dijadikan acuan oleh penulis lain untuk dapat mengurangi kesulitan belajar yang dialami oleh siswa dengan penerapan model dan metode pembelajaran yang lebih efektif dan sesuai.

\begin{tabular}{ll}
\hline Key Words & ABSTRACT \\
\hline Description & Description of Physics Lesson Learning Difficulties at Junior High \\
Difficulty Learning & School Students in Semarang, This study purpose to find and describe \\
Physics & the types of learning problems of junior high school students in the city of \\
& Semarang. The research sample in this study was VIII grade junior high \\
school students in Semarang City who were clustered based on the results \\
of the examination of the results of the national examination. Data analysis \\
was carried out descriptively, the data used in this study were data on \\
student learning outcomes in class VIII light material. \\
The results of the analysis of the learning outcomes of junior high school \\
students in the city of Semarang in general include indicators of learning \\
difficulties counting 41.48\%, difficulties understanding the concept of \\
42.3\% and difficulty interpreting symbols and converting units $37.89 \%$. \\
The description of learning difficulties can be used by students by being \\
able to use methods and methods of learning that are more effective and \\
appropriate
\end{tabular}

Copyright (C) 2018 Institut Agama Islam Negeri Kudus. All Right Reserved

\section{Pendahuluan}

Dalam sebuah pembelajaran seorang peserta didik kadang menghadapi sebuah hambatan dalam belajar atau yang dikenal dengan istilah kesulitan belajar. Kesulitan belajar merupakan suatu keadaan dimana peserta didik tidak dapat belajar secara wajar, disebabkan adanya ancaman, hambatan maupun gangguan dalam belajar (Djamarah, 2011). Jika seorang siswa mengalami kegagalan atau kurang berhasil dalam hasil belajar, hal itu berarti ada kesulitan yang dihadapi selama pembelajaran (Hamalik, 2006). Kesulitan belajar pada sekolah menengah pertama salah satunya terjadi pada mata pelajaran IPA materi fisika. Mata pelajaran IPA materi fisika menuntut intelektualitas yang relatif tinggi. Checkley (2010) menjelaskan bahwa fisika merupakan sebuah mata pelajaran yang penting serta patut dipahami oleh siswa 
pada era kemajuan teknologi dan informasi saat ini.

Hasil observasi yang telah dilakukan oleh penulis terhadap beberapa sekolah di Kota Semarang menunjukkan hasil prestasi belajar masih kurang maksimal. Guru dihadapkan dengan berbagai permasalahan diantaranya karakterisktik siswa yang beraneka ragam dalam kegiatan pembelajaran di sekolah. Ada siswa yang dapat menempuh kegiatan belajarnya secara lancar dan berhasil tanpa mengalami kesulitan, namun di sisi lain tidak sedikit pula siswa yang justru dalam belajarnya mengalami berbagai kesulitan. Kesulitan belajar siswa ditunjukkan oleh adanya hambatan-hambatan tertentu untuk mencapai hasil belajar (Slameto, 2003) .

Menurut Wahyudi (2006), ciri-ciri anak yang sedang mengalami berkesulitan belajar antara lain anak yang mengalami kesulitan dalam mengerjakan tugas-tugas akademik sekolah, sehingga prestasi belajar yang dicapai jauh dari potensi yang sebenarnya. Sedangkan Rusilowati (2006) menjelaskan penyelidikanpenyelidikan yang dapat dilakukan untuk mengetahui kesulitan belajar siswa adalah dengan mengadakan observasi, analisis, interview, tes diagnostik, dan memanfaatkan dokumentasi .

Dari kenyataan diatas menunjukkan bahwa penguasaan siswa terhadap mata pelajaran fisika pada sekolah menengah pertama (SMP) masih bermasalah dan permasalahan yang dihadapi berbeda. Untuk itulah peneliti disini merasa penting untuk melalukan penelitian mengenai adanya kesulitan belajar fisika pada sekolah menengah pertama (SMP) di Kota Semarang yang dihadapi oleh siswa.

\section{Metode}

Lokasi penelitian dilakukan di Kota Semarang. Populasi penelitian dalam penelitian ini adalah siswa SMP di Kota Semarang. Sedangkan sampel pada penelitian ini merupakan siswa SMP kelas VIII yang ditentukan secara cluster sampling menurut peringkat sekolah dilihat dari hasil nilai ujian nasional. Identitas sekolah sampel dan jumlah sampel yang terpilih sebagai sampel dapat dilihat pada Tabel 1 .

Tabel 1. Sampel Penelitian berdasarkan Peringkat Sekolah

\begin{tabular}{llc}
\hline & Sekolah & $\begin{array}{c}\text { Jumlah } \\
\text { Sampel }\end{array}$ \\
\hline Kategori I & SMP N 2 Semarang & 29 \\
& SMP I Al Azhar 14 & 22 \\
Kategori II & SMP N 27 Semarang & 32 \\
& SMP Nurul Islam & 25 \\
Kategori III & SMP N 35 Semarang & 24 \\
& SMP Kartika III-2 & 18 \\
\hline
\end{tabular}

Data yang diperoleh dalam penelitian ini merupakan data hasil belajar siswa. Setelah data terkumpul dilakukan reduksi data yang bertujuan untuk memfokuskan pada hal-hal yang akan diteliti yaitu menganalisis jawaban siswa yang telah dipilih dalam penelitian (Sugiyono. 2010).

Analisis data dilakukan secara deskriptif. Apabila siswa membuat kesalahan dari setiap langkah dalam menyelesaikan soal tes uraian, maka siswa tersebut dinyatakan mengalami kesulitan mempelajari fisika.

\section{Hasil dan pembahasan}

Hasil analisis data menunjukkan variasi tingkat kesulitan belajar pada masing masing indikator. Presentase tingkat kesulitan belajar fisika pada siswa SMP di Kota Semarang secara global dapat dilihat pada Grafik 1 berikut:

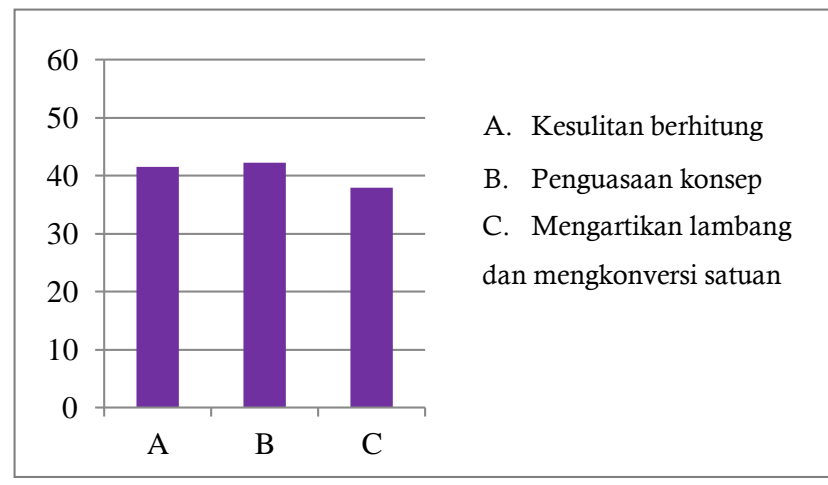

Grafik 1. Grafik Presentase Kesulitan Belajar

Fisika Siswa SMP di Kota Semarang

Berdasarkan data hasil penelitian yang diperoleh dari tes tertulis yang dikerjakan oleh 
sampel objek penelitian didapatkan persentase secara global adalah sebagai berikut: (1) untuk kesulitan belajar pada indikator kesulitan berhitung mempunyai persentase $41,48 \%$ (2) Indikator kesulitan pemahaman konsep mempunyai persentase $42,3 \%$ dan (3) Indikator kesulitan mengartikan lambang dan mengkorvensi satuan diperoleh besarnya persentase adalah $37,89 \%$. Secara global indikator kesulitan belajar paling besar adalah kesulitan pemahaman konsep, dibawahnya terdapat kesulitan berhitung dan yang mempunyai presentase terkecil adalah indikator mengartikan lambang dan mengkonversi satuan.

Dari hasil kesuluruhan data tersebut, dapat kita kelompokkan menjadi dalam tiga kategori sekolah yang menjadi sampel pada penelitian ini. Hasil presentase kesulitan belajar pada ketiga kategori sekolah adalah sebagai berikut:

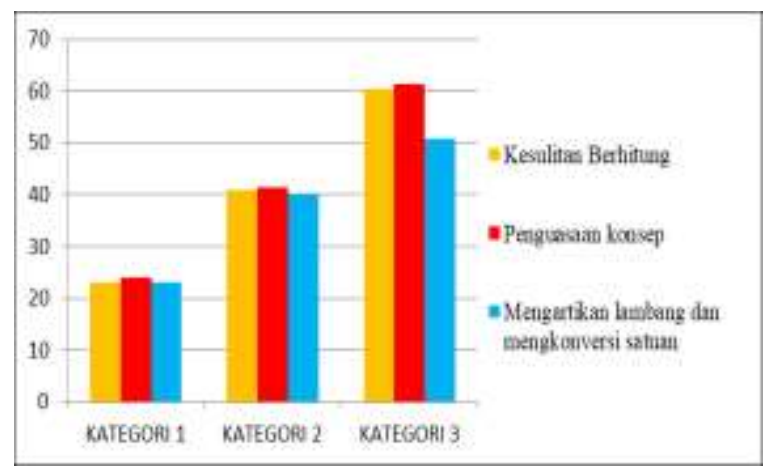

Grafik 2. Grafik Presentase Kesulitan Belajar Fisika Siswa SMP di Kota Semarang Pada Tiap Kategori Sekolah

Berdasarkan tingkat kategori sekolah yang menjadi sampel penelitian dilihat dari data hasil penelitian diperoleh persentase untuk setiap indikator tersebut di atas sebagai berikut: (1) Pada sekolah kategori I mempunyai kesulitan berhitung sebesar $23,04 \%$, penguasaan konsep sebesar 24,12\%, dan kesulitan mengartikan lambang dan mengkonversi satuan sebesar 23,04\% (2) Pada sekolah kategori II mempunyai kesulitan berhitung sebesar $41,97 \%$, penguasaan konsep sebesar 41,46\%, dan kesulitan mengartikan lambang dan mengkonversi satuan sebesar 40,92\% (3) pada sekolah kategori III mempunyai kesulitan berhitung sebesar $60,42 \%$, penguasaan konsep sebesar $60,32 \%$, dan kesulitan mengartikan lambang dan mengkonversi satuan sebesar $50,70 \%$.

Dari ketiga kategori tersebut merupakan sampel dari sekolah negeri dan sekolah swasta. Untuk presentase kesulitan belajar siswa SMP pada sampel sekolah negeri dan sekolah swasta dapat dilihat pada Grafik 3 dan Grafik 4 sebagai berikut:

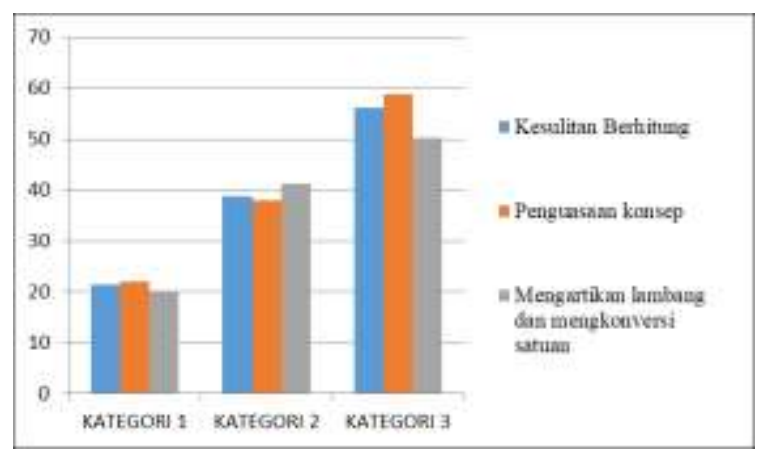

Grafik 3. Grafik Presentase Kesulitan Belajar Fisika Siswa SMP di Kota Semarang Kategori Sekolah Negeri

Hasil penelitian untuk kelompok sekolah negeri diperoleh persentase untuk setiap indikator tersebut di atas sebagai berikut: (1) Pada sekolah negeri kategori I mempunyai kesulitan berhitung sebesar $21,42 \%$, penguasaan konsep sebesar 22,13\%, dan kesulitan mengartikan lambang dan mengkonversi satuan sebesar 20,14\% (2) Pada sekolah negeri kategori II mempunyai kesulitan berhitung sebesar $38,76 \%$, penguasaan konsep sebesar 37,88\%, dan kesulitan mengartikan lambang dan mengkonversi satuan sebesar $41,22 \%$ (3) pada sekolah negeri kategori III mempunyai kesulitan berhitung sebesar $56,05 \%$, penguasaan konsep sebesar 58,8\%, dan kesulitan mengartikan lambang dan mengkonversi satuan sebesar $50,12 \%$. 


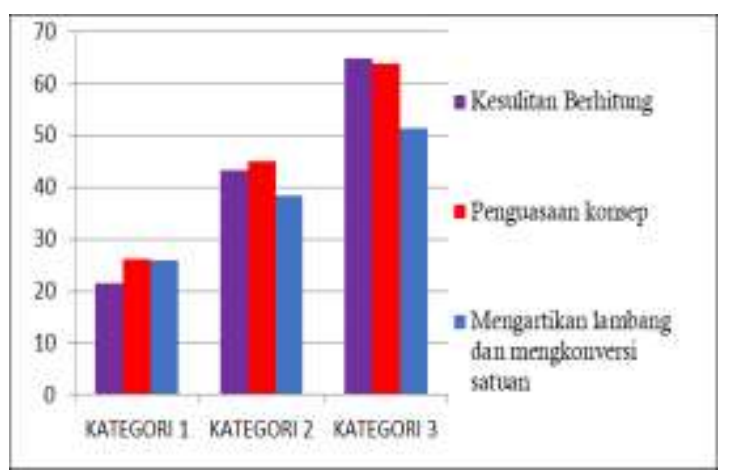

Grafik 4. Grafik Presentase Kesulitan Belajar Fisika Siswa SMP di Kota Semarang Kategori Sekolah Swasta

Kemudian hasil penelitian untuk kelompok sekolah swasta diperoleh persentase untuk setiap indikator tersebut di atas sebagai berikut: (1) Pada sekolah swasta kategori I mempunyai kesulitan berhitung sebesar $21,42 \%$, penguasaan konsep sebesar 26,12\%, dan kesulitan mengartikan lambang dan mengkonversi satuan sebesar 25,94\% (2) Pada sekolah swasta kategori II mempunyai kesulitan berhitung sebesar $43,21 \%$, penguasaan konsep sebesar 45,04\%, dan kesulitan mengartikan lambang dan mengkonversi satuan sebesar $38,33 \%$ (3) pada sekolah swasta kategori III mempunyai kesulitan berhitung sebesar $64,79 \%$, penguasaan konsep sebesar $63,85 \%$, dan kesulitan mengartikan lambang dan mengkonversi satuan sebesar 51,36\%.

Hasil diatas menunjukkan bahwa adanya perbedaan presentase kesulitan belajar pada masing masing indikator yakni kesulitan berhitung, penguasaan konsep serta indikator mengartikan lambang dan mengkonversi satuan. Adanya kesulitan belajar pada indikator kesulitan berhitung ini sesuai dengan pendapat Marantika (2007) yang menjelaskan bahwa dalam pembelajaran fisika sering digambarkan dan dijelaskan oleh simbol dan formula matematika. Oleh sebab itu, pemahaman konsep fisika juga sangat membutuhkan adanya pemahaman mengenai konsep-konsep dasar matematika, sedangkan Rusilowati (2006) juga menyatakan bahwa salah satu penyebab kesulitan belajar fisika siswa adalah karena lemahnya kemampuan matematis. Dengan rendahnya kemampuan matematis siswa, maka siswa akan semakin tidak memiliki kemampuan untuk menjabarkan rumus-rumus yang dipelajari.

Pada indikator penguasaan konsep sesuai dengan yang ada dalam penelitian oleh Arief (2012) yang menjelaskan bahwa penguasaan konsep mempunyai presentase yang cukup besar dalam kesulitan belajar fisika. Adanya data yang tercantum dalan hasil analisis diatas jelas menampakkan bahwa penguasaan konsep juga menjadi kesulitan belajar yang dialami oleh siswa Sekolah Menengah Pertama di Kota Semarang.

Selanjutnya pada Indikator mengartikan lambang dan mengkonversi satuan siswa juga mengalami adanya kesulitan belajar yang nampak pada hasil analisis data yang telah disampaikan. Hal ini sejalan dengan penelitian oleh Charli (2017) yang menyatakn adanya kesulitan pada indikator mengartikan lambang dan mengkonversi satuan. Menurut Charli, siswa mengalami kesulitan dalam menuliskan simbolsimbol yang digunakan untuk fisika.

Kesulitan belajar materi fisika pada siswa Sekolah Menengah Pertama (SMP) harus segera diatasi. Kesulitan belajar fisika yang berkelanjutan menyebabkan siswa kesulitan dalam memahami konsep-konsep fisika selanjutnya (Suyanto, 2017). Salah satu cara yang dapat dilakukan guru adalah melakukan diagnosis yang bertujuan untuk mengidentifikasi jenis dan penyebab kesulitan belajar. Hal ini didukung oleh penelitian yang dilakukan Rusilowati (2006) yang menjelaskan bahwa untuk mengatasi masalah kesulitan belajar ini harus didiagnosa terlebih dahulu dan selanjutnya diambil tindakan untuk mengatasi masalah tersebut

Adanya perbedaan presentase kesulitan belajar yang berbeda dapat disebabkan oleh adanya faktor kesulitan belajar yang berbeda. Hal ini sesuai dengan penelitian yang dilakukan 
oleh Haqiqi (2018) yang menjelaskan bahwa kesulitan belajar dipengaruhi oleh adanya beberapa faktor yakni faktor internal dan faktor eksternal. Faktor kesulitan belajar yang dialami oleh siswa dalam faktor internal yang meliputi aspek bakat, minat, motivasi dan intelegensi dan faktor eksternal meliputi fasilitas sekolah, guru, sarana prasarana dan aktivitas siswa.

\section{Simpulan}

Kesulitan belajar fisika pada siswa SMP di Kota Semarang meliputi indikator kesulitan belajar berhitung diperoleh presentase sebesar 41,48 \%, kesulitan pemahaman konsep 42,3\% dan kesulitan mengartikan lambang dan mengkoversi satuan $37,89 \%$. Terdapat perbedaan yang dilihat dari ketiga kategori sekolah yang dikarenakan adanya faktor - faktor kesulitan yang berbeda-beda.

Hasil penelitian ini dapat digunakan sebagai landasan awal untuk menentukan model ataupun pembelajaran yang bervariasi pada tiap sekolah. Hal ini disebabkan karena masing masing sekolah yang memiliki jenis dan tingkat kesulitan belajar yang berbeda-beda

\section{Referensi}

Arief, Meizuvan Khoirul. 2012. Identifikasi Kesulitan Belajar Pada Siswa RSBI: Studi Kasus Di RSMABI Se Kota Semarang. Unnes Physics Education Journal. Volume. 1 No. 2

Charli, Leo. dkk. 2018. Kesulitan Siswa Dalam Menyelesaikan Soal Fisika Pada Materi Suhu dan Kalor di Kelas X SMA ArRisalah Lubuklinggau Tahun Pelajaran 2016/2017. Journal of Education and Instruction (JOEAI). Volume 1, No 1

Checkley, D. 2010. High School Students' Perceptions of Physics, Faculty of Education. Lethbridge, Canada

Hamalik, Oemar. 2006. Proses Belajar Mengajar. Bandung: Bumi Aksara.

Haqiqi, Arghob Khofya. 2018. Analisis Faktor Penyebab Kesulitan Belajar IPA Siswa SMP Kota Semarang. Edu Sains: Jurnal Pendidikan Sains \& Matematika. Volume. 6, No. 1, 37-43
Marantika, I. 2007. Pengaruh Keaktifan Organisasi Ekstrakurikuler dan Motivasi Belajar Terhadap Prestasi Belajar Mahasiswa. Skripsi. Malang: Fakultas Ekonomi Universitas Negeri Malang.

Rusilowati, Ani. 2006. Profil Kesulitan Belajar Fisika Pokok Bahasan Kelistrikan Siswa SMA di Kota Semarang. Jurnal Pendidikan Fisika Indonesia. 4 (2), 100106.

Slameto. 2003. Belajar dan Faktor-Faktor yang Mempengaruhinya. Jakarta: Gramedia

Sugiyono. 2010. Metode Penelitian Pendidikan Pendekatan Kuantitatif, Kualitatif dan $R \& D$ (Edisi Kelima). Bandung: Alfabeta.

Suyanto, 2017. Pengaruh Strategi Pembelajaran Dan Bakat Terhadap Hasil Belajar Pemahaman Konsep Teknik Otomotif Di SMKN 1 Trenggalek. Jurnal Pendidikan Profesional. Volume 5, No. 1

Wahyudi. 2006. Pelaksanaan Remedial Bagi Anak Berkesulitan Belajar Membaca Permulaan Kelas II SD . Jurnal Guru Dinas Pendidikan Kota Padang Panjang. Volume 03 No.1 hal 81 